\title{
The Analysis of the Training Program Influence on the Development of Swimming Achievements at the Club
}

\author{
R.Agung Purwandono Saleh ${ }^{1}$, Tandiyo Rahayu ${ }^{2}$, Hari Amirullah Rachman ${ }^{3}$, Setya Rahayu ${ }^{4}$ \\ \{purwandono.agung@yahoo.co.id ${ }^{1}$ \} \\ ${ }^{1}$ Graduate School Universitas Negeri Semarang \\ ${ }^{2}$ Universitas Negeri Yogyakarta \\ ${ }^{3}$ Universitas Pembangunan Nasional "VETERAN" Yogyakarta
}

\begin{abstract}
The national swimming sport of the Special Region of Yogyakarta (DIY) was fail to get a medal in the 2016 Pekan Olahraga Nasional in Bandung. The purpose of this study was to analyze the components of the training program that had been a guideline for coaches especially in swimming in the process of training. The data were gained through observation, interviews and questionnaires. The subjects of this study were eight coaches from eight swimming clubs who are members of the FKRS (Forum Klub renang Sleman). There are five components of the exercise that are used as indicators, namely: planning exercises, implementation of swimming exercises, implementation of physical conditioning, training methods and the availability of training facilities and equipment. Based on the analysis obtained results, namely: the availability of training facilities and equipment is still less supportive. This is related to the availability of swimming pools for training.
\end{abstract}

Keywords: analysis, training, program, swimming, club

\section{Introduction}

Swimming clubs are training forums that train athletes from the most basic level, such as preparation and training for athletes from beginning to learn until training to improve performance. Service quality represents a sport club's service evaluation of staff, programme, and installation by its members [1]. Development of sport has to do with the collaboration of some important components of sports towards achieving a high-level performance in such spor [2]. So far the pattern of the development of swimming sports still relies on the association as the spearhead of coaching. The contributions of Indonesian national swim team athletes all come from clubs. The best achievement was achieved at the Asian Games in Indonesia in 2018, where Indonesia was able to reach the top 4 rankings. But in terms of getting a medal in swimming sports, Indonesia has not been able to obtain a single medal. The best achievement for the swimming medal at the Asian Games was won in 1990 in Beijing China. At that time through two swimmers Richard Sam Bera and Wirmandi Sugriat were able to win two bronze medals in the $100 \mathrm{~m}$ free breaststroke and $200 \mathrm{~m}$ breaststroke, after which the Indonesian swim team could not win a medal.

On a national scale, the achievements of the Yogyakarta Special Region swimmers have shown positive contributions. But the last swimming athlete who represented the Indonesian swimming team at international events such as Sea Games namely Wilton Leo and Boyke Dharma at the Sea Games in Jakarta in 1987. The participation of the athletes from the Yogyakarta Regional Swimming in national events was also never interrupted. Although after 
PON in 1989 in Jakarta up to PON in 2016 in Bandung, West Java, swimming have not been able to produce a medal again. Starting from the decline of national sports achievements, research studies are needed, one of which is to analyze more specifically the performance of swimming clubs in Sleman District, Special Region of Yogyakarta, which has been fostering athletes.

The purpose of this study was to analyze the components of the training program that had been a guideline for coaches especially in swimming in the process of training. There are five components of the exercise that are used as indicators, namely: planning exercises, implementing swimming exercises, implementing physical conditioning, training methods and the availability of training facilities and equipment. Swimming is often seen as a teenage sport where you're supposed succeed at an young age and if you don't start early or don't practise huge amounts, you might get categorized as being too old or not having potential [3]. In the process of coaching towards the highest achievement, the club is in a strategic place, because it is in the leading position and spearheading achievement coaching [4]. For coaching education to impact coaching practices, the learning sources and modes are key. The top three reasons to start coaching swimming were: been asked to coach by the federation, club, parents, coaches, etc.; to contribute to athletes' learning and development; and wanting to give back to their sport [5]. The actual conditions in the field whether it is true that during this time the decline in achievement occurred due to the foundation of guidance at the association level was not solid and was not properly fostered [6]. So that through this analysis study, it is expected to provide benefits that can provide important information, important recommendations as problem solving and good solutions for KONI, Pengda PRSI, Pengkab PRSI, swimming clubs, coaches, parents, and athletes themselves in implementing coaching achievements in this sport.

\section{Methods}

This research is a survey where the subjects are swimming coaches who are members of swimming clubs. The swimming clubs are member of the Forum Klub Renang Sleman (FKRS) in Sleman district namely 1.) Yuso SC, 2.) Dolphin SC, 3.) Jogja Aquatik SC, 4.) Dash SC, 5.) Tirta Amanda SC, 6.) Satria Mataram Aquatik SC, 7.) Selabora SC, 8.) Arwana SC. The research population are coaches who members of the Swimming Federation in Sleman District, as many as eight coaches. Good coaches conduct better programs and help athletes achieve their best results [7]. Determination of samples using purposive sampling technique. This technique was chosen because researchers already know the characteristics of the population, so proportional samples are needed that are in accordance with the purpose of this study.

Data taken is about the principal components of training in training programs prepared and implemented by coachess which include: : 1.) planning exercises, 2.) implementation of swimming exercises, 3.) implementation of physical conditioning, 4.) training methods and 5.) the availability of training facilities and equipment. Retrieval of data through questionnaires was arranged based on the assessment criteria model, where score 1 was very less, score 2 was less, score 3 was enough, score 4 was good, and score 5 was very good. Methods of collecting data through observation and interviews through questionnaire filling methods. Data analysis techniques using computing. Test validity using total statistical items. Test reliability with the Cronbach Alpha scale. Science and technology have greatly assisted WAIS coaches to physically and mentally prepare each individual athlete for competition [8]. Furthermore, the data is described based on an analysis of the five components of the above training principles. 


\section{Results and Discussion}

The validity test of result for factor analysis with item total statistical coefficient value is $>0$. 30. And the result of item reliability test with reliability scale Cronbach(alpha) for each variable is $>0.634$.

Table 1. Frequency distribution and percentage of assessment result score

\begin{tabular}{|c|c|c|c|c|c|c|c|c|c|c|c|c|c|}
\hline \multirow{3}{*}{$\begin{array}{l}\text { Components } \\
\text { assessed }\end{array}$} & \multirow{2}{*}{\multicolumn{2}{|c|}{1}} & \multicolumn{4}{|c|}{ Score } & \multirow{2}{*}{\multicolumn{2}{|c|}{4}} & \multirow{2}{*}{\multicolumn{2}{|c|}{5}} & \multirow{3}{*}{$\begin{array}{c}\text { Amou } \\
\text { nt of } \\
\text { value }\end{array}$} & \multirow{3}{*}{$\begin{array}{c}\text { Amoun } \\
\mathrm{t}(\%)\end{array}$} & \multirow{3}{*}{$\begin{array}{l}\text { Amou } \\
\text { nt of } \\
\text { sample }\end{array}$} \\
\hline & & & & 2 & & 3 & & & & & & & \\
\hline & f & $\%$ & $\mathbf{f}$ & $\%$ & f & $\%$ & f & $\%$ & f & $\%$ & & & \\
\hline Planning exercises & $\begin{array}{l}2 \\
9\end{array}$ & 36.3 & $\begin{array}{l}3 \\
4\end{array}$ & $\begin{array}{c}42 . \\
5\end{array}$ & $\begin{array}{l}1 \\
1\end{array}$ & $\begin{array}{c}13 . \\
8\end{array}$ & 4 & 7.5 & 0 & 0 & 80 & 100 & 8 \\
\hline \multirow{2}{*}{$\begin{array}{l}\text { Implementation of } \\
\text { swimming exercises } \\
\text { Implementation of } \\
\text { physical } \\
\text { conditioning }\end{array}$} & $\begin{array}{l}2 \\
6\end{array}$ & 46.4 & $\begin{array}{l}2 \\
1\end{array}$ & $\begin{array}{c}37 . \\
5\end{array}$ & 7 & $\begin{array}{c}12 . \\
5\end{array}$ & 2 & 3.6 & 0 & 0 & 56 & 100 & 8 \\
\hline & $\begin{array}{l}2 \\
6\end{array}$ & 46.4 & $\begin{array}{l}1 \\
9\end{array}$ & $\begin{array}{c}33 . \\
9\end{array}$ & 9 & $\begin{array}{c}16 . \\
1\end{array}$ & 2 & 3.6 & 0 & 0 & 56 & 100 & 8 \\
\hline Training Methods & 8 & 25.0 & $\begin{array}{l}1 \\
7\end{array}$ & $\begin{array}{c}53 . \\
1\end{array}$ & 6 & $\begin{array}{c}18 . \\
8\end{array}$ & 1 & 3.1 & 0 & 0 & 32 & 100 & 8 \\
\hline $\begin{array}{l}\text { Availability of } \\
\text { training facilities } \\
\text { and equipment }\end{array}$ & $\begin{array}{l}4 \\
6\end{array}$ & 82.1 & 9 & $\begin{array}{c}16 . \\
1\end{array}$ & 0 & 0 & 1 & 1.8 & 0 & 0 & 56 & 100 & 8 \\
\hline
\end{tabular}

Table 2. Planning Exercise

\begin{tabular}{ccc}
\hline Category & $\mathrm{n}$ & $\%$ \\
\hline Very good & 0 & 0.0 \\
Good & 7 & 87.5 \\
Enough & 1 & 12.5 \\
Less & 0 & 0.0 \\
Total & 8 & 100 \\
\hline
\end{tabular}

Table 4. Implementation of Physical Conditioning

\begin{tabular}{ccc}
\hline Category & $\mathrm{n}$ & $\%$ \\
\hline Very good & 0 & 0.0 \\
Good & 4 & 50.0 \\
Enough & 4 & 50.0 \\
Less & 0 & 0.0 \\
Total & 8 & 100 \\
\hline
\end{tabular}

Table 3. Implementation of Swimming Exercises

\begin{tabular}{ccc}
\hline Category & $\mathrm{n}$ & $\%$ \\
\hline Very good & 0 & 0.0 \\
Good & 0 & 0.0 \\
Enough & 8 & 100 \\
Less & 0 & 0.0 \\
Total & 8 & 100 \\
\hline
\end{tabular}

Table 5. Training Methods

\begin{tabular}{ccc}
\hline Category & $\mathrm{n}$ & $\%$ \\
\hline Very good & 3 & 37.5 \\
Good & 4 & 50.0 \\
Enough & 1 & 12.5 \\
Less & 0 & 0.0 \\
Total & 8 & 100 \\
\hline
\end{tabular}


Table 6. Availability of training facilities and equipment

\begin{tabular}{ccc}
\hline Category & $\mathrm{n}$ & $\%$ \\
\hline Very good & 2 & 25.0 \\
Good & 0 & 0.0 \\
Enough & 3 & 37.5 \\
Less & 3 & 37.5 \\
Total & 8 & 100 \\
\hline
\end{tabular}

The results of the analysis of the two tables above, can be explained as follows: based on the answers Planning exercises from 10 questions in the research instrument questionnaire, it can be seen that from 8 swimming coaches showed the results of 1 coach in a percentage of $12.5 \%$ indicating that at the level of quality enough, 7 coaches as a percentage of $87.5 \%$ showing good quality level. The training program functions as a control of the achievement improvements achieved by the athlete [9].

Implementation of swimming exercises, the answers of 7 questions in the research instrument: questionnaire, it can be seen that from 8 swimming coaches showed the results of 8 coaches in a percentage of $100 \%$ indicating that the quality level are enough. Implementation of physical conditioning on the answers of 7 questions in the research instrument: questionnaire, it can be known that from 8 swimming coaches showed the results of 4 coaches in a percentage of $50 \%$ indicating that the level of quality are good, 4 coaches as a percentage of $50 \%$ showed on the quality level are enough. Since this type of loading is low in volume with most swimming programs, the implementation of a dryland resistance training program becomes increasingly important to increase both peak forces and rate of force development in the lower body to enhance swim start performance [10]. Training methods on the answers from 6 questions in the research instrument: questionnaire, it can be known that from 8 swimming coaches showed the results of 3 coaches in a percentage of $37.5 \%$ showing a very good level of quality, 4 coaches in a percentage of $50 \%$ showing at a good level of quality, 1 coach as a percentage of $12.5 \%$ indicate that the quality is enough. The success of strengthening training methods in improving the performance of swimming athletes is inseparable from the seriousness of the subject in carrying out the material in accordance with the agreed upon provisions [11]. In this case, the accomplishment of the top national sport achievement is pursued through a national sport coaching pattern which refers to pyramid system [12].

Availability of training facilities and equipment on the answers of 7 questions in the research instrument: questionnaire, it can be seen that from 8 swimming coaches showed the results of 2 coaches in a percentage of $25.0 \%$ showed that the level of quality are very good, 3 coaches as much as $37.5 \%$ showed on the level of quality are enough, 3 coaches as a percentage $37.5 \%$ indicate that the quality level are less. Optimizing the role of stakeholders in fostering swimming sports can be seen from the various efforts made by stakeholders, starting from the formation of an organization that houses swimming, empowering athletes and coaches, as well as providing various facilities and infrastructure and supporting facilities for swimming activities [13]. 


\section{Conclusion}

Based on the results of the above research, the analysis of the five components of the training program principles, the presence of coaches who are lacking in the use of facilities and equipment available during the implementation of the development of the achievements of the athletes. The limitation of swimming pools that cannot be used for training and maximally because together with public visitors.

This is a major limiting factor for the smooth implementation of the training program. In addition there are main supporting factors that can facilitate the implementation of the training program, namely the high motivation of swimmers to train intensively, the ability of the trainer to support the athletes and the role of parents in supporting achievement.

In addition, the management of the swimming club must also be addressed, so that the club has sufficient funds to be able to rent a swimming pool by themselves. So that the athlete's training process can be maximized and not disturbed by other clubs and general swimmers. 


\section{References}

[1] Jos M.C. Schijns, Marjolein C.J. Caniëls, Joska Le Conté .: The Impact of Perceived Service Quality on Customer Loyalty in Sports Clubs. Vol 24 pp 43-71 .International Journal of Sport Management, Recreation \& Tourism (2016)

[2] Gunawan I \& Purwanto S .: An Evaluation of Swimming Coaching Programs. Vol. 278, pp. 519-522. 2nd Yogyakarta International Seminar on Health, Physical Education, and Sport Science (2018)

[3] Mattila R .: Early specialization and recommendations for swimming. Degree Programme in Sports Coaching and Management. Haaga Helia Helsinki. pp 15 (2018)

[4] Satria M H, Tandiyo R, Soegiyanto KS.: Evaluasi Program Pembinaan Olahraga Sepakbola di Sekayu Youth Soccer Academy (SYSA) Kabupaten Musi Banyuasin Sumatera Selatan. Vol 1 No.2 pp. 162-166. Journal of Physical Education and Sports (2012)

[5] Chroni S, Medgard M, Nilsen DA, Sigurjónsson T \& Solbakken T .: Profiling the Coaches of Norway. A national survey report of sports coaches \& coaching. University of Applied Science, Inlan Norway. pp 50 (2018)

[6] Triyasari A, Soegiyanto K.S, \& Soekardi.: Evaluasi Pembinaan Olahraga Senam Artistik di Klub Senam Kabupaten Pati dan Kabupaten Rembang. Vol 5 No.1 pp 41-46. http://journal.unnes.ac.id/sju/index.php/jpes (2016)

[7] Pyke F.: Going for Gold., champion form the Western Australian Institut of Sport. West Australian Institut of Sport, Perth Australia. pp 76 (2009)

[8] Pyke F.: Going for Gold., champion form the Western Australian Institut of Sport. West Australian Institut of Sport, Perth Australia. pp 84 (2009)

[9] Imbroda OJ , Castillo R, Alfonso\& Chinchilla Minguet, J .: Sports Management, Leadership in the Organization. Vol 2 No.2 pp 56-65. Journal of Physical Education and Sports Management (2015)

[10] Shiqi Thng, Pearson S \& Keogh J .: The Relationship Between Dry-Land Resistance Training And Start Performance in Competitive Swimming: a Brief Review. Vol 36 No $224 \mathrm{pp}$ 927-930. 36th Conference of the International Society of Biomechanics in Sports. Auckland, New Zealand (2018)

[11] Sutiyono B, Hari Setijono, Tandiyo R \& Hari A R .: Increasing Technical Performance through Style Improvement Exercise on Swimming Athlete. Vol 247 pp 75-79. Advances in Social Science, Education and Humanities Research (ASSEHR) (2018)

[12] Adzalika AR, Soegiyanto \& Rumini .: The Evaluation of Athletes' Achievement Coaching Program of Measurable Sports. Vol 8 No.1 pp 56-61. https://journal.unnes.ac.id/sju/index.php/jpes/article/view/26843.( 2019)

[13] Imtihansyahi R, Sarman M, \& Supriadi H .: The Role of Stakeholders in The Development of Swimming Sports Branch in Tanah Laut Regency, Indonesia. Vol 4 pp 57-67. European Journal of Social Sciences Studies (2019) 